\title{
„Biblioteczka Poradni Dydaktyczno-Wychowawczej przy Kuratorium Okręgu Szkolnego Wileńskiego" jako forma pomocy dla nauczycieli szkoły powszechnej na Wileńszczyźnie i Nowogródczyźnie w II Rzeczypospolitej
}

\section{Wprowadzenie}

Z chwilą odrodzenia się II Rzeczypospolitej Wileńszczyzna i Nowogródczyzna, podobnie jak cały obszar Kresów Wschodnich, były opóźnione cywilizacyjnie względem zachodniej i centralnej części kraju. Dodatkowo, na skutek działań wojennych w latach 1920-1921 część infrastruktury i gospodarki uległa zniszczeniu. Jednym z podstawowych celów rządu II Rzeczpospolitej było podjęcie wszelkich działań, aby zespolić ten obszar z resztą ziem polskich. Odrodzona Rzeczpospolita, zróżnicowana społecznie i ekonomicznie, nie była również krajem jednorodnym etnicznie i wyznaniowo. Przeszło trzydzieści procent społeczeństwa stanowiły mniejszości narodowe oraz wyznaniowe ${ }^{1}$, które głównie mieszkały na

* Dr, Uniwersytet w Białymstoku, Wydział Pedagogiki i Psychologii, Katedra Historii Wychowania, 15-328 Białystok, ul. Świerkowa 20.

1 Według Jerzego Tomaszewskiego, w II RP było 35,4\% mniejszości, zaś Janusz Żarnowski podaje, że 34\%. Henryk Chałupczak i Tomasz Browarek szacują liczbę mniejszości na 11,2 mln osób, co stanowi 35,1\% społeczeństwa, w tym Ukraińców około 5 mln, Żydów 3,1 mln, Białorusinów 1,9 mln, Niemców 830 tys., Litwinów 180 tys., Rosjan 100 tys., Czechów 40 tys., Cyganów 30 tys., Słowaków 7 tys., Ormian 5,5 tys., Tatarów 5 tys. oraz Karaimów 1 tys. Zob. J. Żarnowski, Społeczeństwo Drugiej Rzeczypospolitej, Warszawa 1973; tenże, Społeczeństwo polskie Drugiej Rzeczypospolitej, Warszawa 1973; tenże, Społeczeństwo Polski międzywojennej, Warszawa 1969; Polska 1918-1939. Praca - technika - społeczeństwo, Warszawa 1990; Społeczeństwo i kultura II Rzeczypospolitej, Warszawa 1982; J. Tomaszewski, Rzeczpospolita wielu narodów, Warszawa 1985; tenże, Ojczyzna nie tylko 
terenach przygranicznych. Problem zróżnicowania etnicznego Kresów Wschodnich był wielokrotnie podejmowany w dyskusjach politycznych ówczesnego rządu, rozwiązanie wszelkich konfliktów etnicznych stanowiło podstawę zachowania bezpieczeństwa wewnętrznego i stabilizacji wschodnich granic Polski.

Jednocześnie przez okres dwudziestolecia międzywojennego częścią strategii państwa polskiego wobec mniejszości była polityka oświatowa realizowana poprzez ideologie wychowawcze wdrażane na gruncie działań edukacyjnych. Po przewrocie majowym rozpoczęto realizowanie sanacyjnego ideału wychowania państwowego, opartego na pracy na rzecz dobra państwowego. Wbrew głoszonym hasłom o neutralnym narodowościowo wychowaniu państwowym, zwłaszcza na ziemiach północno-wschodnich nie zrezygnowano z wpajania poprzez edukację świadomości polskiej². Kwestie narodowościowe i wyznaniowe wielokrotnie podkreślali czołowi przedstawiciele myśli pedagogicznej II Rzeczypospolitej ${ }^{3}$. W założeniach ideologicznych próbowano określić miejsce mniejszości w procesie wychowawczym ${ }^{4}$. Szczególną rolę w polityce oświatowej wobec mniejszości narodowych i grup religijnych zamieszkujących Kresy Wschodnie przypisywano okręgowi szkolnemu wileńskiemu ${ }^{5}$. Do zadań kuratorium należały opieka, kontrola, nadzór pedagogiczny i administracyjny wszystkich przedszkoli, szkół powszechnych, zawodowych, średnich i wyższych oraz wszelkich form kształcenia pozaszkolnego. Kuratorium wileńskie opracowywało programy szkolne, uwzględ-

Polaków. Mniejszości narodowe w latach 1918-1939, Warszawa 1985; tenże, Mniejszości narodowe w Polsce w XX wieku, Warszawa 1991; H. Hołuszko, Mniejszości narodowe i etniczne w Polsce, Warszawa 1992; H. Chałupczak, T. Browarek, Mniejszości narodowe w Polsce 1918-1995, Lublin 2000, s. 22.

${ }^{2}$ W. Śleszyński, Bezpieczeństwo wewnętrzne w polityce państwa polskiego na ziemiach północno-wschodnich II Rzeczypospolitej, Warszawa 2007, s. 188.

${ }^{3}$ Na temat polityki oświatowej wobec mniejszości w II RP zob. O. Bouffałł, Ochrona mniejszości w prawie narodów, Warszawa 1928; F. Brzeziński, Prawa mniejszości, Warszawa 1920; S. Chruściel, Szkoła państwowa a mniejszości narodowe w Polsce i za granicą, Lwów 1938; A. Deryna, Międzynarodowe zobowiązania Polski w zakresie szkolnictwa mniejszości narodowych, Lwów 1927; S. Grabski, Szkoła na ziemiach wschodnich, Warszawa 1927; J. Kornecki, Szkolnictwo dla mniejszości narodowych w Polsce, Warszawa 1928; K. Srokowski, Sprawa narodowościowa na kresach wschodnich, Kraków 1924; L. Wasilewski, Sprawa kresów i mniejszości narodowych w Polsce, Warszawa 1925; Studia o szkolnictwie $i$ oświacie mniejszości narodowych w XIX i XX wieku, red. S. Walasek, Wrocław 1994; E. Koko, W nadziei na zagładę Polski ruch socjalistyczny wobec kwestii narodowościowej w Polsce (1918-1939), Gdańsk 1995.

${ }^{4}$ U. Wróblewska, Polityka oświatowa państwa polskiego wobec mniejszości narodowych, grup etnicznych i wyznaniowych zamieszkujących Kresy Wschodnie w II RP, "Nauka” 2011, nr 2, s. $109-124$.

${ }^{5}$ Okręg szkolny wileński, jako jeden z okręgów szkolnych, został utworzony na mocy rozporządzenia Ministra Wyznań Religijnych i Oświecenia Publicznego w 1922 roku z siedzibą kuratora w Wilnie. W 1927 r. w wyniku rozporządzenie Ministra Wyznań Religijnych i Oświecenia Publicznego z dnia 24 lutego 1927 r. o zmianie granic okręgów szkolnych białostockiego, poleskiego i wileńskiego nastąpiła reorganizacja i wówczas z okręgu szkolnego białostockiego i polskiego wyodrębniono województwo nowogródzkie, które włączono do okręgu wileńskiego. W 1937 roku okręg szkolny wileński poszerzono o cztery powiaty województwa białostockiego: augustowski, grodzieński, suwalski i wołkowyski. Dz. Urz. RP 1922, Nr 34, poz. 283; Dz. Urz. RP 1927, Nr 20, poz. 155-157; M. Pęcherski, M. Świątek, Organizacja oświaty w Polsce w latach 1917-1977: podstawowe akty prawne, Warszawa 1978, s. 33-36, 233-234. 
niając różnorodną strukturę etniczną Wileńszczyzny i Nowogródczyzny. Istotną formą działalności Kuratorium Okręgu Szkolnego Wileńskiego (dalej: K.O.S. Wileńskiego) były publikacje naukowe, podręczniki i wytyczne pedagogiczne wydawane w ramach serii „Biblioteczka Poradni Dydaktyczno-Wychowawczej przy K.O.S. Wileńskim. Pomoc dla nauczyciela realizującego program publicznej szkoły powszechnej na Wileńszczyźnie i Nowogródczyźnie”, które uwzględniały historyczne uwarunkowania regionu. Ze względu na brak podręczników, trudności z dotarciem do informacji dotyczących regionu materiały dla nauczycieli były wydawane w dwóch równoległych seriach.

Celem artykułu jest scharakteryzowanie serii wydawniczej K.O.S. Wileńskiego, która upowszechniała wiedzę o regionie i dawała praktyczne wskazówki nauczycielom pracującym w szkołach Wileńszczyzny i Nowogródczyzny.

\section{Cele i zadania „Biblioteczki Poradni Dydaktyczno-Wychowawczej przy Kuratorium Okręgu Szkolnego Wileńskiego"}

Zgodnie z założeniami programowymi oraz ze statutem szkół powszechnych zadaniem szkoły było przygotowanie dzieci do pełnienia przyszłych obowiązków wobec państwa przez wszechstronne wychowanie religijno-moralne, społeczno-obywatelskie, estetyczne, utylitarno-gospodarcze oraz umysłowe ${ }^{6}$. Od 1934 roku, z chwilą wprowadzenia zmian programowych uwzględniających zasadę aktualizacji i regionalizacji treści historycznych ${ }^{7}$, Ministerstwo Wyznań Religijnych i Oświecenia Publicznego zalecało kuratoriom wydawanie publikacji, które upowszechniałyby wiedzę historyczną i kulturową z danego regionu. Kuratorium wileńskie swoje publikacje wydawało pod wspólnym tytułem jako „Biblioteczka Poradni Dydaktyczno-Wychowawczej przy Kuratorium Okręgu Szkolnego Wileńskiego. Pomoc dla nauczyciela realizującego program publicznej szkoły powszechnej na Wileńszczyźnie i Nowogródczyźnie"».

6 Wytyczne przy opracowaniu planu wychowawczego szkoły powszechnej, „Biblioteczka Poradni Dydaktyczno-Wychowawczej przy Kuratorium Okręgu Szkolnego Wileńskiego” (dalej K.O.S. Wileńskiego), Seria Druga, nr 10, Wilno 1934, s. 6-7.

7 Zasady aktualizacji i regionalizacji zagadnień narodowościowych obowiązywały wówczas, gdy w programach szkolnych (klasa V szkoły powszechnej) nie uwzględniono tematów dotyczących mniejszości narodowych, które zamieszkiwały obszar, w którym znajdowała się szkoła. Na przykład: przy zagadnieniu Gospodarka Bony na kresach należało, dokonując aktualizacji, przedstawić opiekę rządu polskiego pomajowego na kresach wschodnich; przy zagadnieniu Kniaziowie Ostrogscy w służbie dla państwa należało podkreślić kwestie stosunku ludności rosyjskiej do Polski, sabotaż jednostek i zgodną współpracę ogółu, tolerancję polską i szkoły rosyjskie w okresie międzywojennym. Regionalizacja treści kształcenia polegała na uwzględnianiu specyficznych cech regionu, w którym znajdowała się szkoła. E. Magiera, Problem mniejszości narodowych w jędrzejewiczowskiej reformie programu historii dla szkół powszechnych w okresie międzywojennym, [w:] A. Bilewicz, S. Walasek, Rola mniejszości narodowych w kulturze i oświacie polskiej w latach 1700-1939, Wrocław 1998, s. 229-235.

8 Wytyczne..., obwoluta. 
Biblioteczka rozpoczęła swoje prace wydawnicze od 1934 roku, bodźcem do opracowania serii był nowy program nauki historii w publicznych szkołach powszechnych trzeciego stopnia, który uwzględniał aktualne tematy. Chociażby w klasie VI proponowano nauczycielom realizację tematów dotyczących działalności Józefa Piłsudskiego oraz etapów odbudowywania państwa polskiego ${ }^{9}$. Dodatkowo w programie podkreślano potrzebę wiązania treści historycznych z regionem z uwzględnieniem jego specyfiki. „W ciągu całego kursu, podobnie jak w klasie $\mathrm{V}$, należy z obrazami wskazanymi w materiale nauczania, wiązać najważniejsze wiadomości z dziejów danej miejscowości i dziejów regionu, w którym leży szkoła, uzupełniając stosownie odpowiednie punkty programu, różne dla różnych miejscowości”'10. Wprowadzona zasada aktualizacji i regionalizacji treści szkolnych zmuszała nauczycieli do samodzielnego poszukiwania materiałów regionalnych.

W celu ułatwienia działalności dydaktycznej i wychowawczej Kuratoria rozpoczęły pracę nad przygotowaniem cyklu zawierającego treści regionalne. Publikacje przygotowywały osoby, które zawodowo zajmowały się opracowywanym zagadnieniem. Każda książka opatrzona była ilustracjami, a na końcu zawierała wykaz bibliograficzny. Broszury wydawane w serii „Biblioteczki” miały za zadanie utorowanie drogi przyszłym podręcznikom regionalnym lub dodatkom regionalnym do podręczników ogólnopolskich oraz czytankom do nauki języka polskiego. Celem publikacji było „dostarczenie nauczycielom szkół powszechnych, pracującym na terenie okręgu wileńskiego w jak najszybszym czasie możliwie wyczerpujących pomocy niezbędnych do realizacji nowych programów dotyczących zagadnień historii i kultury naszego terenu, zagadnień ogólnodydaktycznych i wychowawczych”11. W „Biblioteczce” nauczyciel miał odnaleźć pomoc w nurtujących go problemach oświatowych ${ }^{12}$.

Zanim powstała seria „Biblioteczki”, większość tekstów dotyczących regionu ukazywała się jako bezpłatny dodatek do „Dziennika Urzędowego Kuratorium Okręgu Szkolnego Wileńskiego” lub jako artykuły w „Sprawach Nauczycielskich”. Ponieważ zapotrzebowanie na teksty regionalne było większe, nauczyciele potrzebowali wsparcia w postaci materiałów merytorycznych i wskazówek dydaktycznych, dlatego od 1934 roku zaczęto równoległe wydawanie dwóch serii

${ }^{9}$ Program nauki historii w publicznych szkołach powszechnych trzeciego stopnia przewidywał w klasie VI następujące tematy z historii: Józef Piłsudski; Przygotowanie do walki o niepodległość; Wybuch wojny światowej; Wymarsz kadrówki dnia 6 sierpnia 1914 r.; Obrazki z walk Legionów i działań Polskiej Organizacji Wojskowej; Obrazki z wędrówek i walk innych formacji polskich; 11 listopada 1918 odrodzenie Polski; Z walki o wyzwolenie się dzielnic; Naczelnik Państwa Józef Piłsudski; Obrona Polski w 1920 r.; Granice i sąsiedzi; Konstytucja Państwa Polskiego i jej zmiana w roku 1926; Prezydent Rzeczypospolitej; Zniszczenie Polski przez wojnę i jej odbudowa, port Gdański; Polska a inne państwa świata; Polska w Lidze Narodów. Zob. Program nauki historii w publicznych szkołach powszechnych trzeciego stopnia, punkt 4, Lwów 1933.

${ }^{10}$ W. Arcimowicz, Marszałek Józef Piłsudski w Wilnie i na Wileńszczyźnie. Wypisy, Seria Pierwsza „Biblioteczki Poradni Dydaktyczno-Wychowawczej przy K.O.S. Wileńskiego”, nakładem „Dziennika Urzędowego K.O.S. Wileńskiego", Pomoc dla nauczyciela realizującego program publicznej szkoły powszechnej na Wileńszczyźnie i Nowogródczyźnie, nr 1; Bezpłatny dodatek do nr 1, 2, 3 „Dziennika Urzędowego K.O.S. Wileńskiego", Wilno 1934, s. 5.

11 Wytyczne..., s. 3.

12 Tamże. 
„Poradni Dydaktyczno-Wychowawczej przy K.O.S. Wileńskim”. Pierwsza seria była zbiorem treści dotyczących historii Wileńszczyzny i Nowogródczyzny. Publikacje regionalne, pod redakcją doktora Władysława Arcimowicza, wydawano w formie bezpłatnych dodatków do „Dziennika Urzędowego Kuratorium Okręgu Szkolnego Wileńskiego".

Natomiast seria druga była odpłatna. Odpowiedzialny za dobór zróżnicowanych treści i materiałów był Stanisław Turski, który przyjmował zamówienia i wpłaty na kolejne egzemplarze ${ }^{13}$. Druga seria jako „Biblioteczka Poradni Dydaktyczno-Wychowawczej przy Kuratorium Okręgu Szkolnego Wileńskiego” wychodziła począwszy od sierpnia 1934 roku, co dwa miesiące ukazywały się po trzy dwuarkuszowe tomiki. Koszt przedpłaty rocznej za osiemnaście numerów wraz z przesyłką wynosił 7,20 zł, którą to sumę można było rozłożyć na raty i należało ją wpłacić bezpośrednio na konto wydawcy, Stanisława Turskiego. Niską cenę skalkulowano bez uwzględniania zysku, co miało zachęcić nauczycieli do zakupu broszur regionalnych. Od stanu zebranych funduszy zależała realizacja planów wydawniczych, dlatego aby zmobilizować czytelników do wcześniejszego zakupu, cena tomiku poza przedpłatą była dwukrotnie wyższa ${ }^{14}$. W 1934 roku w ramach drugiej serii planowano wydać drukiem zagadnienia dotyczące Wileńszczyzny i Nowogródczyzny - historii, etnografii, rozwoju przemysłu, handlu, działalności władców oraz działań narodowowyzwoleńczych ${ }^{15}$.

Serię pierwszą w 1934 roku rozpoczęła publikacja poświęcona działalności Józefa Piłsudskiego, była najobszerniejsza - liczyła ponad 90 stron i składała się z sześciu części, które zawierały przedruki z gazet, prasy codziennej, publikacji oraz dzieł Marszałka ${ }^{16}$. Natomiast serię drugą rozpoczynała praca zbiorowa zawierająca Wytyczne przy opracowaniu planu wychowawczego szkoły powszechnej, wydana w Wilnie 1934 roku jako pomoc dla nauczycieli realizujących program publicznej szkoły powszechnej ${ }^{17}$.

Zalecenia dla nauczycieli z zakresu kształcenia i wychowania uczniów szkół powszechnych publikowano na łamach „Biblioteczki Poradni Dydaktyczno-Wychowawczej przy Kuratorium Okręgu Szkolnego Wileńskiego”.

13 S. Turski projektował również wspólnie z Gracjanem Achrem-Achremowiczem okładki broszur w serii drugiej, w których wykorzystywano motywy sztuki ludowej regionu.

14 Wytyczne..., s. 3.

${ }^{15}$ L. Bejnar, Zygmunt August w Wilnie i na Wileńszczyźnie, nr 1; T. Nagurski, Przemysł i handel województwa wileńskiego i nowogródzkiego, cz. I i II, nr 2-3;T. Łopalewski, Napoleon Bonaparte w Wilnie i na Wileńszczyźnie, nr 4; Tuchowski, Dynowski, Bodzińska, Rzemiosło na Wileńszczyźnie i Nowogródczyźnie, nr 5; Bodzińska, Dynowski, Sztuka ludowa Wileńszczyzny i Nowogródczyzny, cz. I i II, nr 7-8; M. Znamierowska-Prüfferowa, Bartnictwo i łowiectwo na Wileńszczyźnie, nr 9; taż, Rybołówstwo na Wileńszczyźnie, nr 10; taż, Komunikacja wodna na Wileńszczyźnie, nr 11; Turkowski, Dzieje i stan obecny komunikacji lądowej na Wileńszczyźnie i Nowogródczyźnie, nr 12; M. Dunajówna, Prace Filomatów i Filaretów na terenie Wileńszczyzny i Nowogródczyzny, cz. I i II, nr 13-14; K. Bieliński, Powstanie Kościuszkowskie w Wilnie i na Wileńszczyźnie, nr 15; L. Krawiec, Udział Litwy w wojnach na południu Rzeczypospolitej (Turcja, Tatarzy, Wołosza), nr 16; tenże, Udział Litwy w wojnach na północy Rzeczypospolitej (Krzyżacy, Szwedzi), nr 17; tenże, Aleksander Jagiellończyk na ziemiach dawnego Księstwa Litewskiego, nr 18.

16 W. Arcimowicz, Marszałek...

17 Wytyczne... 
Dwie serie „Biblioteczki Poradni Dydaktyczno-Wychowawczej przy K.O.S. Wileńskiego" zawierały materiały merytoryczne dotyczące regionu oraz praktyczne wskazówki dydaktyczne dla nauczycieli z zakresu wychowania i kształcenia uczniów szkół powszechnych Wileńszczyzny i Nowogródczyzny.

W okresie międzywojennym szkoła swoje zadania społeczne wypełniała poprzez program i organizację nauczania oraz program i organizację pracy wychowawczej. Jednym z podstawowych elementów oświaty w II Rzeczypospolitej było wychowanie, stanowiące fundament pożądanych postaw i wartości przyszłego obywatela. W celu realizacji wychowania, w ramach „Biblioteczki” wydano w 1934 roku broszurę zawierającą wskazówki wychowawcze dla nauczycieli. W Wytycznych przy opracowaniu planu wychowawczego szkoły powszechnej ${ }^{18}$ zwrócono uwagę, że „program wychowawczy powinien uwzględniać indywidualne warunki i możliwości każdej szkoły, poziom dzieci i potrzeby środowiska"19, podkreślając tym samym znaczenie regionalizmu w edukacji okresu międzywojennego. Proponowano nauczycielom, aby nawyki oraz pożądane cechy wyrabiali i ćwiczyli w uczniach stopniowo, w zależności od możliwości dziecka, warunków szkoły i środowiska. Wytyczne zawierały pożądany tok wprowadzania zagadnień - proponowano, aby w pierwszej kolejności wytłumaczyć dziecku i dotrzeć do niego poprzez intelekt, a następnie przejść do ćwiczeń, korzystając przy tym z form angażujących dziecko emocjonalnie, takich jak: uroczystości szkolne, święta czy wycieczki szkolne. W poradniku dla nauczycieli podkreślano skuteczność indywidualizacji wychowania oraz znaczenie nauczyciela, którego postawa i zachowanie miały stanowić przykład do naśladowania dla młodzieży. Wychowanie w każdej szkole miało uwzględniać warunki lokalne oraz odbywać się stale, w każdym miejscu. Proces wychowawczy, odbywający się na lekcji, przerwie, schodach, podwórku czy w organizacjach szkolnych, sklepikach szkolnych, poprzez swój permanentny charakter był efektywny i skuteczny ${ }^{20}$. W codziennej pracy nauczycielom służyć miał również poradnik metodyczny z treściami regionalnymi i wskazówkami ich wykorzystania ${ }^{21}$ oraz publikacje z zakresu dydaktyki, psychologii, logopedii czy poradnictwa zawodowego ${ }^{22}$.

18 Wytyczne..., s. 3.

19 Wytyczne..., s. 4.

20 Wytyczne..., s. 9-12.

21 T. Żukowska, W. Arcimowicz, Jak korzystać z działu regionalnego Biblioteczki Poradni Dydaktyczno-Wychowawczej przy K.O.S. Wileńskim, „Biblioteczka...”, nr 14; Bezpłatny dodatek do nr 10 „Dziennika Urzędowego K.O.S. Wileńskiego”, Wilno 1935.

${ }^{2}$ H. Trzebińska-Bodzińska, Sztuka ludowa Wileńszczyzny i Nowogródczyzny a szkoła, „Pomoc dla nauczyciela realizującego program publicznej szkoły powszechnej na Wileńszczyźnie i Nowogródczyźnie”, nr 30, Bezpłatny dodatek do nr 3 „Dziennika Urzędowego K.O.S. Wileńskiego”, Wilno 1937; Koło Wileńskie Stowarzyszenia Nauczycieli Szkół Zawodowych. Informator szkół zawodowych okręgu szkolnego wileńskiego, „Pomoc...”, nr 32, Bezpłatny dodatek do nr 5 „Dziennika Urzędowego K.O.S. Wileńskiego”, Wilno 1937; J. Głębocki, Zwalczanie wad wymowy na terenie szkoły powszechnej, Cz. 1. Uwagi ogólne, fefanie, kekanie, łełanie, reranie, szeplenienie, „Pomoc...”, nr 38, Bezpłatny dodatek do nr 1 „Dziennika Urzędowego K.O.S. Wileńskiego”, Wilno 1938; tenże, Zwalczanie wad wymowy na terenie szkoły powszechnej, Cz. 2. Brak dźwięków, obniżanie głosu, chrypka, bełkotanie, nosowość, jąkanie się, „Pomoc...”, nr 39, Bezpłatny dodatek do nr 2 „Dziennika Urzędowego 
W procesie wychowania ważna była wiedza historyczna, będąca podstawą świadomości społecznej. Trudno w okresie międzywojennym przecenić rolę i znaczenie autorytetów w kształtowaniu postaw przyszłych pokoleń. Osobą, która zajmowała znaczące miejsce w panteonie wychowawców II Rzeczypospolitej, był bez wątpienia Józef Piłsudski. W 1934 roku, jako pomoc dydaktyczną dla nauczycieli, W. Arcimowicz opracował zbiór tekstów i przedruków dotyczących działalności Marszałka. Warto też wspomnieć, że w kwietniu 1934 roku przypadała 15. rocznica wyzwolenia Wilna i dlatego też przygotowano materiał do pogadanek dla nauczycieli o „Wielkim synu Wileńszczyzny, który Wilno dla Polski pomimo zewnętrznych i wewnętrznych przeszkód i sprzeciwów uratował i który dla Wilna uratował i wzmocnił polską kulturę"23. Część pierwsza dotyczyła dziecinnych i szkolnych lat J. Piłsudskiego ${ }^{24}$. Część druga zawierała materiały dotyczące działalności jego w Wilnie i na Wileńszczyźnie w latach poprzedzających wybuch wojny światowej25. Część trzecia dotyczyła źródeł z wyprawy wileńskiej, a czwarta poświęcona została wskrzeszeniu Uniwersytetu w Wilnie ${ }^{26}$. W piątej części

K.O.S. Wileńskiego”, Wilno 1938; Informator szkół zawodowych okręgu szkolnego wileńskiego, oprac. przez „Poradnię Zawodową” Stowarzyszenia „Służba Obywatelska” w Wilnie, „Pomoc...”, nr 51, Bezpłatny dodatek do nr 6-7 „Dziennika Urzędowego K.O.S. Wileńskiego”, Wilno 1939.

${ }^{23}$ W. Arcimowicz, Marszałek Józef Piłsudski w Wilnie i na Wileńszczyźnie, s. 7.

${ }^{24}$ W pierwszej części książki W. Arcimowicza Marszałek Józef Piłsudski w Wilnie i na Wileńszczyźnie opublikowano następujące wypisy: H. Cepnik, Józef Piłsudski twórca niepodległego Państwa Polskiego, Warszawa 1934; St. Hińcza, Pierwszy żołnierz odrodzonej Polski, Katowice 1931; J. Piłsudski, Wspomnienia własne o latach dziecinnych i szkolnych, [w:] Jak stałem się socjalistą. Pisma, mowy i rozkazy, t. II; M. Opałek, Modrzewiowy dwór, przedruk z Antologii. Pieśń o Józefie Piłsudskim; J. Piłsudski, Tradycje powstania styczniowego w okolicach rodzinnych Józefa Piłsudskiego, [w:] J. Jędrzejewicz, Józef Piłsudski, Warszawa 1920; Z. Zawiszanka, Świt wielkiego dnia, Warszawa 1933; W. Sieroszewski, „Płomyk” 1933, nr 10-12; J. Kaden-Bandrowski, Wyprawa Wileńska, Warszawa 1921.

${ }^{25}$ Na temat pracy konspiracyjnej J. Piłsudskiego w książce W. Arcimowicza znajdowały się następujące teksty: H. Cepnik, Józef Piłsudski, Warszawa 1933; J. Piłsudski, korespondencja wileńska pisana do pisma „Przedświt” w Londynie oraz wybrane teksty z Pism J. Piłsudskiego, m.in.: W sprawie szkolnictwa, Wilno 17 II 1893; W sprawie prześladowań katolicyzmu, Wilno październik 1893; W sprawie pomnika Murawiewa Wieszatela [pisownia oryginalna - przyp. aut.], Wilno listopad 1894.

${ }^{26}$ W części trzeciej wypisów dotyczącej działalności J. Piłsudskiego były następujące przedruki: J. Jędrzejewicz, Rzut oka na przebieg i znaczenie wyprawy wileńskiej, [w:] Józef Piłsudski, Warszawa 1920; S. Rostworowski, Z listu do żony (Z pola walki), „Słowo” 1929, nr 2341; J. Piłsudski, O wyprawie wileńskiej. Z wykładów o „Dowodzeniu podczas wojny”, [w:] Pisma, mowy i rozkazy, t. IV; Znaczenie wyprawy wileńskiej dla Wilna i dla Polski. Przemówienie Inspektora Armii Generała Rydza-Śmigłego na Akademii w dniu 19 kwietnia 1929 r. w X rocznicę wyzwolenia Wilna, „Kurier Wileński” 1929, nr 93; Opis wjazdu J. Piłsudskiego do Wilna, [w:] J. Jędrzejewicz, Zdobycie Wilna w roku 1919, „Głos Prawdy” 1929, nr 108; WX-tą rocznicę wyzwolenia Wilna, wiersz Artura Oppmana (Or-Ot), przedruk, „Kurier Poranny" z dnia 21 IV 1929. W części poświęconej Uniwersytetowi im. Stefana Batorego w Wilnie W. Arcimowicz wybrał następujące teksty: Autograf Józefa Piłsudskiego poświęcony młodzieży Wileńskiej reprodukowany w jednodniówce akademickiej „Alma Mater Vilnensis”, Wilno 1922; Józef Piłsudski, Mowa wygłoszona na uroczystości otwarcia USB w Wilnie 11 października 1919 r., [w:] Pisma, mowy, rozkazy, t. V; Mowa rektora profesora d-ra Michała Siedleckiego wygłoszona na uroczystości otwarcia USB w odpowiedzi na mowę Marszałka, „Kurier Wileński”1929, nr 231; O współpracy Józefa Piłsudskiego przy organizowaniu USB w Wilnie z przemówienia prof. B. Żongołłowicza na akademii w dniu 19 III 1929, „Kurier Wileński” 1929, nr 66; Przemówienie prezesa rady ministrów Kazimierza Świtalskiego na akademii w kościele św. Jana w dniu 10 października 1929, „Kurier Wileński” 1929, nr 233. 
W. Arcimowicz umieścił teksty informujące o walkach dyplomatycznych o Wilno ${ }^{27}$. Wypisy kończyła część zatytułowana Gdy nastał pokój w cieniu miecza, poświęcona sytuacji Wileńszczyzny po 1920 roku $^{28}$. Publikacja jako materiał miała służyć nauczycielom do prowadzenia lekcji, ale jednocześnie była drogowskazem obowiązującej wówczas sanacyjnej ideologii wychowawczej.

Uzupełnienie wiedzy historycznej dotyczącej Wileńszczyzny i Nowogródczyzny stanowiły opracowania historyczne Wandy Niedziałkowskiej-Dobaczewskiej29. Jeden z pierwszych numerów „Biblioteczki” poświęcono pierwszemu w historii wielkiemu hetmanowi litewskiemu Konstantemu Iwanowiczowi Ostrogskiemu $^{30}$. W 1934 roku nakładem „Dziennika Urzędowego K.O.S. Wileńskiego” w serii pierwszej wydano dwie publikacje dotyczące Powstania Styczniowego na Wileńszczyźnie i na terenie województwa nowogródzkiego ${ }^{31}$. Ostatnim wydanym w 1934 roku w serii „Biblioteczki Poradni Dydaktyczno-Wychowawczej przy K.O.S. Wileńskiego" było opracowanie Anny Bujwidówny o przebiegu i znaczeniu Wiosny Ludów na północnym wschodzie Rzeczypospolitej23. W ramach serii pierwszej, wydawanej nakładem „Dziennika Urzędowego Kuratorium Okręgu Szkolnego Wileńskiego", w latach 1934-1939 opublikowano szereg książek o tematyce związanej z historią Wileńszczyzny i Nowogródczyzny ${ }^{33}$.

${ }^{27}$ W piątej części publikacji W. Arcimowicza umieszczono następujące teksty: J. Piłsudski, Stosunek Józefa Piłsudskiego do Litwy przed wyprawą wileńską, Odezwa naczelnego wodza do mieszkańców byłego Wielkiego Księstwa Litewskiego po zdobyciu Wilna, [w:] Pisma, mowy, rozkazy, t. V, Warszawa 1933; Oświadczenie w sprawie Wilna Józefa Piłsudskiego wobec czynu gen Żeligowskiego, Józef Piłsudski bierze na siebie odpowiedzialność za czyn gen. Żeligowskiego, Przemówienie do przedstawicieli ludności w Lidzie; Przemówienie w Wilnie, Walka Józefa Piłsudskiego o Wileńszczyznę w Lidze Narodów, „Czas” 1933, nr 98; E. Słoński, Pieśń o Józefie Piłsudskim, z wiersza Unja z Litwą, A. Krupiński, oprac., Pieśń o Józefie Piłsudskim. Antologia, Zamość 1920.

${ }^{28}$ Teksty zawarte w książce W. Arcimowicza, w części szóstej: Z mowy Marszałka Józefa Piłsudskiego wygłoszonej na VII Zjedzie Legionistów w dniu 12 VIII 1928 w Wilnie, „Kurier Wileński” 1928, nr 183; W. Arcimowicz, Okolice rodzinne Marszałka Józefa Piłsudskiego.

${ }^{29}$ W. Niedziałkowska-Dobaczewska (oprac.), Wilno i Wileńszczyzna w latach 1914-1920, „Biblioteczka...”, nr 2; Bezpłatny dodatek do nr 4, 5 „Dziennika Urzędowego K.O.S. Wileńskiego”, Wilno 1934; taż, Wileńszczyzna i Nowogródczyzna w latach 1920-1937. Sprawy polityczne i społeczne, „Pomoc dla nauczyciela realizującego program publicznej szkoły powszechnej na Wileńszczyźnie i Nowogródczyźnie”, nr 41; Bezpłatny dodatek do nr 4 „Dziennika Urzędowego K.O.S. Wileńskiego”, Wilno 1938.

${ }^{30}$ W. Charkiewicz (oprac.), „Scypjon ruski”: Konstanty Iwanowicz książę Ostrogski, wielki hetman litewski, wojewoda trocki, kasztelan wileński, marszałek ziemi wołyńskiej, starosta łucki, brasławski, winnicki etc., „Biblioteczka...”, nr 4; Bezpłatny dodatek do nr 8-9 „Dziennika Urzędowego K.O.S. Wileńskiego", Wilno 1934.

${ }^{31}$ A. Krzyszkowska, Powstanie styczniowe na Wileńszczyźnie, „Biblioteczka...”, nr 6; Bezpłatny dodatek do nr 10 „Dziennika Urzędowego K.O.S. Wileńskiego”, Wilno 1934; Cz. Zgorzelski, Powstanie styczniowe na terenie województwa nowogródzkiego, „Biblioteczka...”, nr 7; Bezpłatny dodatek do nr 11 „Dziennika Urzędowego K.O.S. Wileńskiego”, Wilno 1934.

${ }^{32}$ A. Bujwidówna, Oddźwięki wiosny ludów na północnym wschodzie Rzeczypospolitej: spisek braci Dalewskich, „Biblioteczka...”, nr 8; Bezpłatny dodatek do nr 12 „Dziennika Urzędowego K.O.S. Wileńskiego", Wilno 1934.

${ }^{33}$ M. Dunajówna, Filomaci w Wilnie, „Biblioteczka...”, nr 9; Bezpłatny dodatek do nr 1-2 „Dziennika Urzędowego K.O.S. Wileńskiego”, Wilno 1935; taż, Filomaci na prowincji, „Biblioteczka...”, nr 10; Bezpłatny dodatek do nr 3 „Dziennika Urzędowego K.O.S. Wileńskiego”, Wilno 1935; B. Zwolski, Wła- 
W ramach Serii Drugiej „Biblioteczki Poradni Dydaktyczno-Wychowawczej przy K.O.S. Wileńskiego" ukazały się prace z zakresu etnografii Wileńszczyzny i Nowogródczyzny. Praca Lucjana Turkowskiego Ludowa wytwórczość rzemieślnicza w wileńskim i nowogródzkim była krótkim opracowaniem zebranych przez autora materiałów z zakresu rzemieślniczej wytwórczości ludowej34. Turkowski, jako pracownik Muzeum Etnograficznego Uniwersytetu Stefana Batorego, z dokładnością badawczą stworzył typologię ludowej wytwórczości rzemieślniczej, uwzględniając wszystkie gałęzie rzemiosła regionu (garncarstwo, tkactwo, kowalstwo, plecionkarstwo). Autor w publikacji przeznaczonej dla nauczycieli analizował także przemiany, jakie zachodziły w wytwórczości ludowej rzemieślniczej w drugiej połowie XIX wieku na skutek zmian kulturowych ziem wileńsko-nowogródzkich. Podobnie etnografię Wileńszczyzny i Nowogródczyzny opisywał Witold Dynowski, który uwzględnił teoretyczne zagadnienia, wprowadzał definicję sztuki ludowej na podstawie literatury przedmiotu oraz stylu ludowego, omawiał zróżnicowane formy zdobnicze budownictwa. Autor precyzyjnie charakteryzował również rzeźbę ludową, ukazując jej przejawy w sprzętach domowych (przęślice, kijanki, maglownice) oraz w przestrzeni sakralnej, w formie kapliczek ${ }^{35}$. Ponieważ cechy etnograficzne wyróżniały Wileńszczyznę i Nowogródczyznę, poświęcono im wiele publikacji. Kowalstwo ludowe w województwie wileńskim opracował Zygmunt Jan Korybutiak, który przygotował także publikację dotyczącą pasterstwa i hodowli zwierzą ${ }^{36}$. Publikacje etnograficzne

dysław IV na ziemiach b. W. Ks. Litewskiego, „Biblioteczka...”, nr 15; Bezpłatny dodatek do nr 8-9 „Dziennika Urzędowego K.O.S. Wileńskiego”, Wilno 1935; T. Bujnicki, Pamiątki historyczne Wileńszczyzny i Nowogródczyzny, cz. 1, „Biblioteczka...”, nr 16, Wilno 1935; cz 2, nr 17, Wilno 1935; H. Cehak-Hołubowiczowa, Zabytki archeologiczne województwa wileńskiego i nowogródzkiego, „Biblioteczka...", nr 18, Wilno 1936; L. Krawiec, J. J. Tochtermann, Tatarzy w Polsce. Próba monografii, „Biblioteczka...”, nr 19; Bezpłatny dodatek do nr 2 „Dziennika Urzędowego K.O.S. Wileńskiego”, Wilno 1936; B. Zwolski, Wileńszczyzna, Nowogródczyzna, Białostocczyzna za Zygmunta III, „Pomoc dla nauczyciela realizującego program publicznej szkoły powszechnej na Wileńszczyźnie i Nowogródczyźnie”, nr 20; Bezpłatny dodatek do nr 3 „Dziennika Urzędowego K.O.S. Wileńskiego”, Wilno 1936; tenże, Wileńszczyzna, Nowogródczyzna, Białostocczyzna za Jana Kazimierza, „Pomoc...”, nr 21, Bezpłatny dodatek do nr 4 „Dziennika Urzędowego K.O.S. Wileńskiego”, Wilno 1936; W. Dobaczewska, Dzieje kultury wileńskiej pomiędzy dwoma powstaniami, „Pomoc...”, nr 29, Bezpłatny dodatek do nr 2 „Dziennika Urzędowego K.O.S. Wileńskiego”, Wilno 1937; B. Zwolski, Wileńszczyzna, Nowogródczyzna, płn.-wschodnia Białostocczyzna za Zygmunta I, „Pomoc..., nr 31, Bezpłatny dodatek do nr 4 „Dziennika Urzędowego K.O.S. Wileńskiego”, Wilno 1937; W. Niedziałkowska-Dobaczewska, Wilno i Wileńszczyzna w latach 1863-1914: dzieje ruchów społecznych i politycznych, „Pomoc...”, nr 40, Bezpłatny dodatek do nr 3 „Dziennika Urzędowego K.O.S. Wileńskiego”, Wilno 1938; taż, Wilno i Wileńszczyzna w latach 1920-1937: sprawy polityczne $i$ społeczne, „Pomoc...”, nr 42, Bezpłatny dodatek do nr 4 „Dziennika Urzędowego K.O.S. Wileńskiego”, Wilno 1938.

${ }^{34}$ L. Turkowski w swojej pracy opisywał wyrób naczyń i przedmiotów z kory, kości i rogu, żłobionych, drążonych oraz bednarstwo, kołodziejstwo, plecionkarstwo, sitarstwo, wiązanie, powroźnictwo, tkactwo, farbiarstwo, smolarstwo, owczynkarstwo, skórnictwo, kamieniarstwo, garncarstwo, kowalstwo. L. Turkowski, Ludowa wytwórczość rzemieślnicza w wileńskim i nowogródzkim, Seria Druga „Biblioteczki...”, nr 8, Wilno 1935.

35 W. Dynowski, Sztuka ludowa Wileńszczyzny i Nowogródczyzny, Seria Druga „Biblioteczki...”, nr 4, Wilno 1935, s. 28.

36 Z. J. Korybutiak, Kowalstwo ludowe w województwie wileńskim, Seria Druga „Biblioteczki...”, nr 23, Wilno 1936; tenże, Hodowla zwierząt domowych i pasterstwo w Wileńskim i Nowogródzkiem, Seria Druga „Biblioteczki...”, nr 24, Bezpłatny dodatek do nr 8 „Dziennika Urzędowego K.O.S. Wileńskiego", Wilno 1936. 
wydawane w Serii Drugiej „Biblioteczki Dydaktyczno-Wychowawczej przy Kuratorium Okręgu Szkolnego Wileńskiego" współcześnie stanowią cenny zbiór udokumentowanych form etnograficznych Wileńszczyzny.

Celem publikacji etnograficznych było nie tylko „zapoznanie nauczycielstwa ze sztuką ludową terenu, ale także zwrócenie uwagi na potrzebę ochrony tej sztuki przed zalewającą ją tandetą , pozbawioną gustu i smaku. Chodziłoby o to, aby nauczycielstwo przyczyniło się do zachowania wśród miejscowej ludności rodzimego stylu, by miejscowe płótna, tkaniny, wzory i motywy znalazły swoje zastosowanie w zdobieniu klas oraz zostały wyzyskane na lekcjach rysunku i zajęć praktycznych. Chodziłoby również o wyzyskanie miejscowego dorobku w tej dziedzinie dla podniesienia kultury estetycznej chat wiejskich, by stosy płócien i tkanin, spoczywające w kufrach, zostały z nich wydobyte i posłużyły do ozdobienia wnętrz chat" ${ }^{37}$. Książki miały być pomocą przy gromadzeniu materiału dotyczącego kultury estetycznej dla charakterystyki rejonu szkoły, zawierały bogaty wykaz literatury, szereg ilustracji ornamentów i wzorów Wileńszczyzny i Nowogródczyzny ${ }^{38}$. W publikacjach historycznych dokładnie analizowano poszczególne miejscowości. W publikacjach dla nauczycieli precyzyjnie wskazywano miejscowości związane z walkami powstańczymi oraz znaczącymi wydarzeniami historycznymi. Szczególnie podkreślano czyny i działania młodych ludzi, aby przybliżyć ich losy do życia uczniów szkół okresu międzywojennego. Wymieniano niemal każdą miejscowość związaną chociażby z niewielkim wydarzeniem historycznym ${ }^{39}$.

Ciekawą propozycją było przygotowanie dokładnego przeglądu treści publikacji wydawanych w ramach serii „Biblioteczki” i dostosowanie ich do zagadnień z programu publicznych szkół powszechnych. Proponowano, aby w klasie II podczas lekcji języka polskiego przy temacie dotyczącym świąt państwowych (6 VIII, $11 \mathrm{XI}, 19 \mathrm{IV}, 12 \mathrm{~V}$ ) nauczyciel wykorzystał z Serii I tomiki 1 i 2, strony 54-63, oraz z Serii II tomy 2-3, 4 i 8. Na podstawie takich informacji nauczyciel wspólnie z uczniami będzie potrafił odnaleźć zjawiska charakterystyczne i ważne dla życia gospodarczego regionu ${ }^{40}$. Podobne materiały można było wykorzystać w klasie III do omawiania zagadnień związanych z zajęciami i pracą mieszkańców wsi i miast. W klasie IV, gdy omawiano wypadki i zdarzenia w najbliższej okolicy, szczególnie należało uwzględnić z Serii I tom 2 dotyczący walk na Wileńszczyźnie 1914-1920 oraz opowiadania z życia Marszałka na tle walki o niepodległość i odrodzenie państwa polskiego zawarte w Serii I w tomie 1. Dokładne wytyczne przygotowano do każdej klasy z historii, geografii i języka polskiego, co miało ułatwić pracę nauczycielowi. Przy niektórych tematach wydawałoby się, że niemożliwe jest odniesienie regionalne. Jednak $w$ takich sytuacjach odwoływano się

37 W. Dynowski, Sztuka ludowa..., s. 39.

38 Tamże.

39 Z publikacji M. Dunajówny poświęconej Filomatom na prowincji dowiadujemy się m.in., że Brasław w 1841 r. odwiedza T. Zan, wracając po wieloletnim wygnaniu do kraju rodzinnego. W 1842 r. współzałożyciel Towarzystwa Filomatów zwiedza również Cerkliszki, Dobrowlany, Dołhinów, Doroszkowicze, Giejstuny, Jaworów, gdzie urodził się Dominik Chodźko, Kamienny Ług, Kobylniki, Kojrany, Konwaliszki. T. Zan w 1820 r. spotkał się z A. Mickiewiczem oraz J. Czeczotem i wspólnie zwiedzili Kościeniewicze, Krasne, Krzywicze, Lachowicze, Lebiedziewo.

40 T. Żukowska, W. Arcimowicz, Jak korzystać z działu regionalnego..., s. 7. 
do analogii w historii. Przykładowo, gdy uczniowie w klasie $\mathrm{V}$ mieli omawiać temat dotyczący Kazimierza Wielkiego jako „budowniczego Lwowa”, przez analogię „można tutaj powiedzieć o Aleksandrze Jagiellończyku, Zygmuncie Auguście czy Stefanie Batorym, którzy rozbudowali Wilno"41. Gdy nauczyciel omawiał założenie Akademii Krakowskiej, mógł nawiązać do Akademii Wileńskiej ${ }^{42}$.

Publikacje zawierały wiele cennych wiadomości z zakresu historii regionu, a dodatkowo charakteryzował je wysoki poziom merytoryczny oraz rzetelność przekazu. Informacje zawarte w broszurach miały być pomocne nauczycielom realizującym program szkoły powszechnej przy opracowywaniu zagadnień z zakresu regionalizacji treści programowych ${ }^{43}$.

\section{Publikacje „Biblioteczki Poradni Dydaktyczno-Wychowawczej przy Kuratorium Okręgu Szkolnego Wileńskiego" jako forma polityki oświatowej wobec mniejszości}

Zróżnicowana etnicznie II Rzeczpospolita musiała także uwzględniać potrzeby oświatowe mniejszości narodowych i grup wyznaniowych. Była to szczególnie delikatna kwestia na obszarze Wileńszczyzny i Nowogródczyzny, gdzie władze oświatowe były czujne i reagowały na wszelkie sytuacje konfliktowe. W programach szkolnych zalecano omawianie zagadnień dotyczących mniejszości w kontekście polityki wewnętrznej państwa. „W celu zbliżenia dzieci do dziejów i kultury mniejszości słowiańskich i litewskiej, należy przy opracowaniu odpowiednich punktów programu zwrócić uwagę na prześladowanie tych mniejszości w państwach zaborczych, oraz ich udział w walkach o niepodległość Polski. W szkołach, gdzie znajduje się młodzież żydowska, należy również omówić udział Żydów w walkach o niepodległość"44.

W realizowanych doktrynach wychowania państwowego propagowanych przez sanację podkreślano potrzebę wzbudzania również w młodzieży polskiej zainteresowania kulturą mniejszości narodowych i wpajania poszanowania dla niej w celu lepszego zrozumienia potrzeby współżycia z mniejszościami w obrębie jednego państwa ${ }^{45}$. W programach szkolnych po 1932 roku zalecano, aby wykorzystywać wiadomości o mniejszościach, które zamieszkiwały okręg szkolnyª.

41 Tamże, s. 5.

42 Tamże, s. 6.

43 Wytyczne..., s. 3.

44 Program nauki w Publicznych Szkołach Powszechnych..., s. 168.

45 Zob. K. Jakubiak, Problem mniejszości narodowych w piłsudczykowskim programie politycznym i doktrynie wychowania państwowego, [w:] Rola mniejszości narodowych w kulturze i oświacie polskiej w latach 1700-1939, red. A. Bilewicz, S. Walasek, Wrocław 1998; U. Świętochowska, Najnowsza historia Polski w programach szkół średnich ogólnokształcących w latach 1918-1939, „Gdańskie Zeszyty Humanistyczne" 1967, Historia, R. X.

${ }^{46}$ Po reformie jędrzejewiczowskiej w programie nauczania historii dla szkół powszechnych określono konieczność zbliżenia młodzieży polskiej do dziejów mniejszości narodowych. Program uwzględniał 
Publikacje wydawane w ramach „Biblioteczki Dydaktyczno-Wychowawczej przy Kuratorium Okręgu Szkolnego Wileńskiego" były jednym z narzędzi uświadamiających społeczeństwo i poprzez swoje treści ukazywały stosunek państwa polskiego do mniejszości. Książka poświęcona działalności J. Piłsudskiego nie była pozbawiona wątków narodowościowych, w jasny sposób ukazywała politykę państwa wobec sąsiadów i mniejszości ${ }^{47}$. „Chętny i umiejętny nauczyciel, pracując na terenie o ludności pod względem narodowościowym mieszanym, znajdzie też tu nieraz momenty, które mu pozwolą aktualizować zagadnienia nawet pokryte patyną wieków, potrafi wyszukać podobieństwa między stosunkiem do Wileńszczyzny wielkich ludzi naszej przeszłości a stosunkiem do niej Wielkiego Budowniczego Państwa Polskiego w naszych czasach"48.

Celem wprowadzania wiadomości o mniejszościach było wzbudzenie w młodzieży polskiej poszanowania wobec innych grup narodowych i wyznaniowych ${ }^{49}$. W uczniach wywodzących się z mniejszości poprzez ukazywanie im dziejów Polski w korelacji z ich własną historią „wzmacniano poczucie przynależności państwowej i odpowiedzialności obywatelskiej wobec państwa"50. Zasadą obowiązującą nauczycieli w zależności od środowiska szkolnego było szersze omawianie tematów z historii Polski z uwzględnianiem mniejszości narodowych ${ }^{51}$. Ciekawym przykładem upowszechniania wiedzy o mniejszościach była monografia pt. Tatarzy polscy, opracowana przez Lucjana Krawca i Jana Jerzego Tochtermanna, wydana jako dodatek do nr 2 „Dziennika Urzędowe-

narodowości i wyznania reprezentowane w danej szkole i środowisku i uświadamiał uczniom znaczenie wspólnej pracy różnych wyznań i narodowości w tworzeniu kultury państwa polskiego. Szczególnie ukazywano dzieje mniejszości słowiańskich, z którymi Polska była najsilniej związana wspólnymi dziejami historycznymi. Program nauki w publicznych szkołach powszechnych trzeciego stopnia. „Historia” (Projekt), Lwów 1933; E. Magiera, Problem mniejszości..., s. 229-235.

${ }^{47} \mathrm{~W}$ jednym z przedruków tekstów J. Piłsudskiego można odnaleźć wyraźną linię jego polityki wobec mniejszości litewskiej i białoruskiej. „Z chwilą gdy wojska polskie zajęły Wilno aktualne się stały sprawy litewskie i białoruskie. Dwa te narody różnią się bardzo w swej dojrzałości wewnętrznej. Białorusini stanowią w znacznym stopniu surowy materiał etnograficzny, który do poczucia swej odrębności narodowej jeszcze nie dorósł. Zbliżenie polsko-białoruskie daje Białorusinom możność samorządnego rozwoju narodowego, popierany przez rząd polski, który będzie dążył do niedopuszczenia do zrusyfikowania Białorusinów, a ci co się zasymilują, to i tak się do tego przyznają. Inaczej rzecz się ma z Litwinami, samowiedza narodowa przeniknęła już szerokie masy ludności, tam nie ma obaw w wynarodowieniu, opieka Polski była by zbyteczna. Natomiast łączą Polskę i Litwę wspólni wrogowie, wspólne interesy gospodarcze - Polska potrzebuje dostępu do morza a Litwa importu towarów polskich, wspólne pretensje do stolicy do Wilna". J. Jędrzejewicz, Rzut oka na przebieg i znaczenie wyprawy wileńskiej, Józef Piłsudski, Warszawa 1920, przedruk w: W. Arcimowicz, Marszałek..., s. 48-49.

${ }^{48}$ W. Arcimowicz, Marszałek..., s. 7.

${ }^{49}$ W. Hoszkowa, Jak realizować nowy program historii, Warszawa 1933; H. Pohoska, Historia w szkole powszechnej, Warszawa 1933, S. Mauersberg, Szkolnictwo powszechne dla mniejszości narodowych w Polsce w latach 1918-1939, Wrocław 1968; E. Magiera, Wychowanie państwowe w szkolnictwie powszechnym Drugiej Rzeczypospolitej, Szczecin 2003, s. 63.

50 Program nauki..., s. 13.

${ }^{51}$ E. Zdrojewski, Zagadnienia wychowania państwowego młodzieży niepolskiej, „Zrąb” 1933, nr 15, s. $12-13$. 
go K.O.S. Wileńskiego” w ramach Serii Pierwszej „Biblioteczki”. Suplement składał się z dwóch części. Pierwsza część, historyczna, była przygotowana przez L. Krawca i dotyczyła dziejów ludności tatarskiej w Rzeczypospolitej Polskiej, natomiast J. J. Tochtermann opracował drugi fragment dodatku w formie monografii wsi tatarskiej Sorok Tatary pod Wilnem ${ }^{52}$. Opracowanie miało na celu zwrócenie większej uwagi na „braterskie współżycie mierzone stuleciami z licznymi zastępami Tatarów osiadłych w naszym kraju niż na bardziej znane walki z hordami tatarskimi" ${ }^{53}$. Przedstawiono ilościowe rozmieszczenie Tatarów w okręgu szkolnym wileńskim. Ponieważ 5366 (z liczącej 5425 osób całej społeczności tatarskiej) Tatarów polskich zamieszkiwało w obrębie Wileńskiego Okręgu Szkolnego, informacje zamieszczone w dodatku miały umożliwić nauczycielom efektywniejszą pracę z uczniami muzułmańskimi ${ }^{54}$. Opracowanie historyczno-monograficzne stanowiło pomoc dla nauczyciela realizującego program publicznej szkoły powszechnej na Wileńszczyźnie i Nowogródczyźnie.

„Nauczycielstwo tutejsze chcąc uwzględnić warunki lokalne przy wykonywaniu programu nieraz będzie musiało wziąć pod uwagę również wychowanków tej narodowości, chlubnie zapisanej w dziejach naszego Państwa"55. Natomiast monografia typowego osiedla tatarskiego miała stanowić dla nauczyciela metodycznie poprawny wzór materiału z zakresu geografii i geologii w związku z poznawaniem terenu ${ }^{56}$. Na zakończenie można jeszcze wspomnieć o zaleceniu Kuratorium Okręgu Szkolnego Wileńskiego, aby biblioteki szkolne zakupiły „Roczniki Tatarskie” jako pisma przedstawiające „obraz o dużej perspektywie, bogatej treści i wyraźnej linii”"57.

W ramach analizowanej serii nie wydano opracowań dotyczących innych mniejszości narodowych czy grup religijnych. Tatarzy jako mała grupa wyznaniowa o znacznym stopniu asymilacji byli wzorcowym przykładem współistnienia mniejszości na ziemiach Rzeczypospolitej. Tatarzy stanowili przykład mniejszości, o której należało mówić i z historią której należało zapoznawać wszystkich ${ }^{58}$. Stąd też zalecenie upowszechniania wiedzy o grupie etnicznej, która wykazywała cechy pożądane politycznie. Poprzez wydanie publikacji dotyczącej mniejszości tatarskiej rząd wykazywał, że wypełnia założenia polityki oświatowej na Kresach Wschodnich wobec innych wyznań i grup etnicznych ${ }^{59}$.

52 L. Krawiec, J. J. Tochtermann, Tatarzy w Polsce, „Biblioteczka Poradni Dydaktyczno-Wychowawczej przy K.O.S. Wileńskiego”, nr 19, Bezpłatny Dodatek do Nr 2 „Dziennika Urzędowego K.O.S. Wileńskiego", Wilno 1936.

${ }^{53}$ L. Krawiec, J. J. Tochtermann, Tatarzy..., s. 3.

54 Tamże, s. 3.

55 Tamże, s. 14.

56 Tamże, s. 3.

57 Od Redakcji, „Rocznik Tatarski” 1935, t. II , s. XXI.

58 U. Wróblewska, Oświata Tatarów w Drugiej Rzeczypospolitej, Warszawa 2012.

59 A. Chojnowski, Koncepcje polityki narodowościowej rządów polskich w latach 1921-1939, Wrocław-Warszawa-Kraków-Gdańsk 1979, s. 24. 


\section{Zakończenie}

Celem „Biblioteczki Dydaktyczno-Wychowawczej przy Kuratorium Okręgu Szkolnego Wileńskiego" było dostarczenie materiałów nauczycielowi, który sam musiał wybierać odpowiednie treści, uwzględniając uwarunkowania miejscowości, w której znajdowała się szkoła. Nauczyciel miał pewną granicę autonomiczności i elastyczności we wprowadzaniu treści regionalnych. Musiał jednak zdawać sobie sprawę z historycznych uwarunkowań miejscowości i podnosić świadomość społeczną. Przybliżał uczniom historię poprzez odwoływanie się do wydarzeń historycznych, które często miały charakter incydentalnych zdarzeń w danej miejscowości. Uczniowie z Mołodeczna dowiadywali się, że w ich miejscowości urodził się i chodził do szkoły Tomasz Zan. Dzieci z Rudnik uczyły się na lekcji historii, że Władysław IV „lubił przebywać w tych lasach, gdzie teraz one zbierają grzyby i jagody, że tu często na polowanie przyjeżdżał" ${ }^{\circ}$. W ten sposób życie narodu i państwa wydawało się młodym obywatelom bliższe. W efekcie zmierzano do tego, aby historia wydawało się częścią codzienności, aby uczniowie posiadali świadomość, że dzieje ich regionu tworzyli ludzie im bliscy, ponieważ „rzeczy bliższe dziecku służą za przejście do rzeczy trudniejszych"61. W celu ułatwienia pracy dydaktyczno-wychowawczej nauczycielowi wydawano publikacje regionalne $z$ dołączonymi skorowidzami miejscowości. Punktem wyjścia postulatów regionalnych było założenie, że „każda miejscowość jest historyczną i o każdej uczniowie mogą się czegoś dowiedzieć"62 $\mathrm{W}$ wytycznych programowych postulowano, aby „wszędzie tam, gdzie treść materiału lokalnego będzie uboga, należy zwrócić uwagę na okolicę nieco dalszą oraz wiązać najważniejsze wiadomości z dziejów danej miejscowości i regionu, w którym leży szkoła uzupełniając stosownie odpowiednie punkty programu i dopasowując do miejscowości"63.

W publikacjach wydawanych w ramach serii „Biblioteczka Poradni Dydaktyczno-Wychowawczej przy Kuratorium Okręgu Szkolnego Wileńskiego" omawiano różne zagadnienia dotyczące Wileńszczyzny i Nowogródczyzny. Treści historyczne, etnograficzne, metodyczne i pedagogiczne miały ułatwić pracę nauczycielowi oraz wskazać mu kierunek myśli oświatowej w II Rzeczypospolitej. Realizacja edukacji regionalnej w obszarze zróżnicowanym etnicznie i narodowo była kwestią trudną i problematyczną. W publikacjach wydawanych w ramach „Biblioteczki Dydaktyczno-Wychowawczej przy Kuratorium Okręgu Szkolnego Wileńskiego" znajdowały się fragmenty dotyczące mniejszości zamieszkujących Wileńszczyznę i Nowogródczyznę. Biorąc jednak pod uwagę znaczną liczbę dzieci wywodzących się z mniejszości, kwestie narodowościowe traktowano margi-

60 T. Żukowska, W. Arcimowicz, Jak korzystać z działu regionalnego..., s. 5.

61 Tamże.

62 Tamże, s. 3.

${ }^{63}$ Program nauki w Publicznych Szkołach Powszechnych trzeciego stopnia z polskim językiem nauczania (tymczasowy) - nakładem Ministerstwa Wyznań Religijnych i Oświecenia Publicznego, s. 294 . 
nalnie. Ukazywano zasługi tych mniejszości, które wykazywały wysoki poziom poprawności w relacjach wobec państwa polskiego.

Na zakończenie należy zwrócić uwagę na wysoki poziom merytoryczny prac publikowanych w ramach serii „Biblioteczki”, do których angażowano wybitnych znawców tematyki, badaczy i pracowników naukowych Uniwersytetu Stefana Batorego w Wilnie. Większość z publikacji obecnie stanowi cenne źródło wiedzy z zakresu historyczno-społecznych uwarunkowań Wileńszczyzny i Nowogródczyzny. Kuratorium Okręgu Szkolnego Wileńskiego należy się także zasłużone uznanie za umiejętne kolportowanie treści regionalnych i udostępnianie ich nauczycielom realizującym program w szkołach powszechnych. Ze względu na brak podręczników „Biblioteczka” była pomocą w realizacji zagadnień regionalnych. Obecnie szkoły według programu realizują treści z zakresu edukacji regionalnej, nauczyciele nie posiadają jednak tak precyzyjnych, rzetelnych wskazówek dydaktycznych. „Biblioteczka Poradni Dydaktyczno-Wychowawczej” jest przykładem współdziałania w obszarze teoretyczno-praktycznym, łączenia wytycznych z podstawy programowej z rzeczywistymi zapotrzebowaniami nauczycieli. 